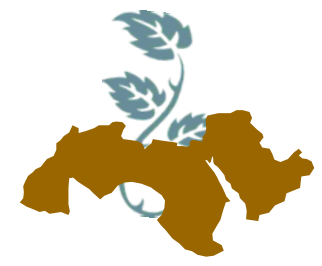

\title{
EFFECT OF SUBSURFACE DRAINAGE SYSTEM DESIGN ON THE SOIL AND WATER MANAGEMENT
}

\author{
Labib $^{1}$ M.M., Hegazi ${ }^{2}$ M.M., El-Bagoury ${ }^{2}$ K.F. and Boulos ${ }^{1}$ M.M. \\ 1. Irrigation and Drainage Dept., Agric. Engineering Research Institute, (ARC), Giza, Egypt \\ 2. Agric. Eng. Dept., Fac. of Agric., Ain Shams Univ., P.O. Box 68 Hadayek Shoubra, 11241, \\ Cairo, Egypt
}

Keywords: Conventional and modified drainage system, Soil salinity, Shallow drain depth, Drainage water and piezometer

\section{ABSTRACT}

A field experiment was carried out to study the effect of drain depth on the drainage water quality and flax productivity. The flax crop was planted during winter season. The field experiment was conducted at the Bahteem Research Station, Qaliubiya Governorate, from November 2015 till April 2016. Two design systems were selected, the first was conventional drainage system (CDS), with drain depth $1.5 \mathrm{~m}$, the second was modified drainage system (MDS), three lateral drain lines were installed to main drain directly. The depth of the lateral drain was $(0.90-1.0) \mathrm{m}$.

The obtained results revealed that the salinity of the average soil profile decreased after the second irrigation onward. The soil salinity percentages of (MDS) decreased by $(47,30$ and 9.5) for $\left(2^{\text {nd }}, 3^{\text {rd }}\right.$ and $\left.4^{\text {th }}\right)$ irrigation, respectively. On the other hand, soil salinity percentages of (CDS) decreased by $(40,32$ and 9$)$ for $\left(2^{\text {nd }}, 3^{\text {rd }}\right.$ and $\left.4^{\text {th }}\right)$ irrigation, respectively. The chloride percentages for average soil profile of (MDS) decreased by $(77,82$ and 54$)$ for $\left(2^{\text {nd }}, 3^{\text {rd }}\right.$ and $\left.4^{\text {th }}\right)$ irrigation, respectively. On the other hand, the chloride percentages of (CDS) decreased by $(70,75$ and 35$)$ for $\left(2^{\text {nd }}, 3^{\text {rd }}\right.$ and $4^{\text {th }}$ ) irrigation, respectively. The $\mathrm{EC}$ values of drainage water of (MDS) decreased from first irrigation onwards. The EC percentages of drainage water salinity of (MDS) decreased by $(10.6,18.2$ and 22.7) for $\left(2^{\text {nd }}, 3^{\text {rd }}\right.$ and $\left.4^{\text {th }}\right)$ irrigation, respectively. On the other hand, the EC percentages of drainage water salinity of (CDS) decreased by (6.3, 5.6 and 24.6$)$ for $\left(2^{\text {nd }}, 3^{\text {rd }}\right.$ and $\left.4^{\text {th }}\right)$ irrigation, respectively. The chloride percentages of drainage water salinity of (MDS) decreased by (22.6, 43 and 14.2) for $\left(2^{\text {nd }}, 3^{\text {rd }}\right.$ and $\left.4^{\text {th }}\right)$ irrigation, respectively. On the other hand, the chloride percentages of (CDS) decreased by $(14.7,32$ and 16.4$)$ for $\left(2^{\text {nd }}, 3^{\text {rd }}\right.$ and $4^{\text {th }}$ ) irrigation, respectively. The piezometer reading showed that the water table levels reaching the soil surface upon irrigation reached low level before the next irrigation. The average values of water table after first irrigation were $(14.5,11 \mathrm{~cm})$ for (MDS) and $(29.5,24 \mathrm{~cm})$ for (CDS) for (L/4, L/2 distance from drain line), respectively. Also the results indicated that the water table level continue decreasing for both systems before $2^{\text {nd }}$ and $3^{\text {rd }}$ irrigation. The results recorded were $(91,82 \mathrm{~cm})$, $(140.5,132 \mathrm{~cm})$ before $2^{\text {nd }}$ irrigation; $(75.5,60 \mathrm{~cm})$, $(133.5,125 \mathrm{~cm})$ before $3^{\text {rd }}$ irrigation for $(\mathrm{L} / 4, \mathrm{~L} / 2$ distance from drain line) for both systems (MDS) and (CDS), respectively. On the other hand data showed that the water table was higher after $2^{\text {nd }}$ irrigation on ward. The results recorded were (16.5, $10 \mathrm{~cm}),(33.5,25 \mathrm{~cm})$ after $2^{\text {nd }}$ irrigation; $(7.5,3$ $\mathrm{cm}),(28,21 \mathrm{~cm})$ after $3^{\text {rd }}$ irrigation for $(\mathrm{L} / 4, \mathrm{~L} / 2$ distance from drain line) for both systems (MDS) and (CDS) respectively. So (MDS) produced drainage water with higher quality and lower salts concentration than the (CDS). At the end of the season the flax productivity was 3.5 ton/fed for both systems. It can be recommended to be used (MDS) with shallow drain depth.

\section{INTRODUCTION}

Under the current economic and population growth as well as the prospective environmental challenges, Egypt is rapidly facing serious water scarcity issue. Water availability per capita rate is already one of the lowest in the world. This is predicted to reach $534 \mathrm{~m}^{3}$ by 2030 (FAO, 2014). Indeed, it is crucial for Egypt to form a comprehen- 
sive strategy that simultaneously aims at enhancing the efficiency of existing usage of irrigation water and boosting water supply from various conventional and non-conventional resources. The relevant question is what the potentials for securing more irrigation water are? Anupam (2013) mentioned that Drainage System is used to control the water table. The change in perspective requires changes in the way drainage systems are designed and managed by reduced salt stored below the root zone as possible, which generally means making drainage as shallow as possible and reported that new drainage design criteria were required to provide adequate protection for crop with clear delineation of water logging and salinity control objectives whilst they minimized drain water salinity and volume. Abd-Eldayem (1998) summarized the requirement of water table and drain depth. A minimum static water table 1.0 $\mathrm{m}$ depth under level is required to maintain favorable soil water conditions for the relatively deeply rooting plants in Egypt (cotton). For reason of economy and outlet depth (main open drains), a maximum field drain depth of $1.5 \mathrm{~m}$ is possible. As the average field drain depth varies between 1.3 and $1.4 \mathrm{~m}$. The lateral drains used in Egypt are corrugated PVC pipes with inside diameter of 72 $\mathrm{mm}$. In addition, they have an average length that varies between 200 and $250 \mathrm{~m}$ with the design slope varies between 0.1 and $0.2 \%$. The design spacing between laterals followed the steady state concept according to Hooughout's Equation. The standard practice has a minimum spacing of $20 \mathrm{~m}$ and a maximum of $60 \mathrm{~m}$. Norman and Randy (1976) showed that shallow subsurface drains (40 $\mathrm{cm}$ deep) remove as much soil water as deeper drains (95 cm deep) during the growing season in the silty clay soil. There was no structural damage to the shallow plastic drain tubes from farming operations. Christen and Skehan (2001) has shown that management of horizontal drains can reduce drainage water salinity, making reuse more feasible and disposal easier because of reduced salinity loads and volumes. FAO (2002) provides data prepared on the relative salt tolerance of various crops at emergence and during growth to maturity. To verify whether a water of certain salinity can be used safely for a particular crop, an annual salt balance can be made to check that the salt in the soil profile does not accumulate or rise periodically above the acceptable salt level chosen for the crop, (FAO, 2007). Usually, deeper drains should allow wider drain spacing because of the increased hydraulic head midway between drains provided that the outlet is deep enough and deeper drains do not necessarily result in a lower average water table, especially for the $30 \mathrm{~m}$ spacing and drain depths below $1.40 \mathrm{~m}$. It can be concluded, that for similar soils as those found in Mashtul, drains at a depth of $(1.20-1.40 \mathrm{~m})$ are an optimum choice (Ritzema, 2009). Ritzema et al (2008) said that subsurface drainage systems, consisting of open and pipe drains with drain spacing varying between 45 and $150 \mathrm{~m}$ and drain depth between 0.90 and $1.20 \mathrm{~m}$, were installed in farmers' fields. The soil conditions determine the most appropriate combination of drain depth and spacing, but the drain depths are considerably shallower than the $1.75 \mathrm{~m}$ traditionally recommended for the prevailing conditions in India.

Grismer (1993) used steady state numerical simulation model to study the effects of depth and spacing of drains on drain discharge and quality in terms of salts concentration and load. Results showed increased drain water salinity as either drain depth or spacing increased, but the increase with drain depth was more pronounced. By changing the design minimum water table depth from 1.2 to $0.9 \mathrm{~m}$ and the depth of drains from 2.4 to $1.5 \mathrm{~m}$ this new drain depth criterion should result in less drain water and lower salt loads being discharged (Ayers et al 1997). Dugas et al (1990) determined the effect of soil type on soybean crop water use from ground water at a depth of $1.0 \mathrm{~m}$. The reduced hydraulic conductivity in the compacted soil and the reduced root length density in the zone above the water table were responsible for the reduction in water use.

The aim of this research concerns in: Reducing the salt loads on conventional drainage network to get water with a high quality suitable for Agriculture. By changing the drain depth, this goal can be achieved and the plant can benefit from drainage water directly or after blending it with fresh water.

\section{MATERIALS AND METHODS}

\section{MATERIALS}

The field experiment was conducted at the Bahteem Research Station, Qaliubiya Governorate, from 15/11/2015 till 15/4/2016. The subsurface irrigation intervals were (44, 40 and 28 days) among the $\left(1^{\text {st }}, 2^{\text {nd }}, 3^{\text {rd }}\right.$ and $\left.4^{\text {th }}\right)$, respectively. 


\subsection{Drainage design system}

\subsubsection{Collector pipes of Conventional Drainage System (CDS)}

The collector No. (20) at western petten Ghonem discharged into the right of Begam main drain. Fig. 1, showed that the collector and subcollector were designed for a discharge rate of 2 $\mathrm{mm} /$ day and the slopes were according to "EPADP Standards", based on the Visser's equation. The diameter of the collector drain pipe was from 150 $\mathrm{mm}$ at the upstream ending up to $250 \mathrm{~mm}$ at the outlet with slope design 0.03-0.06\% and length $1000 \mathrm{~m}$.

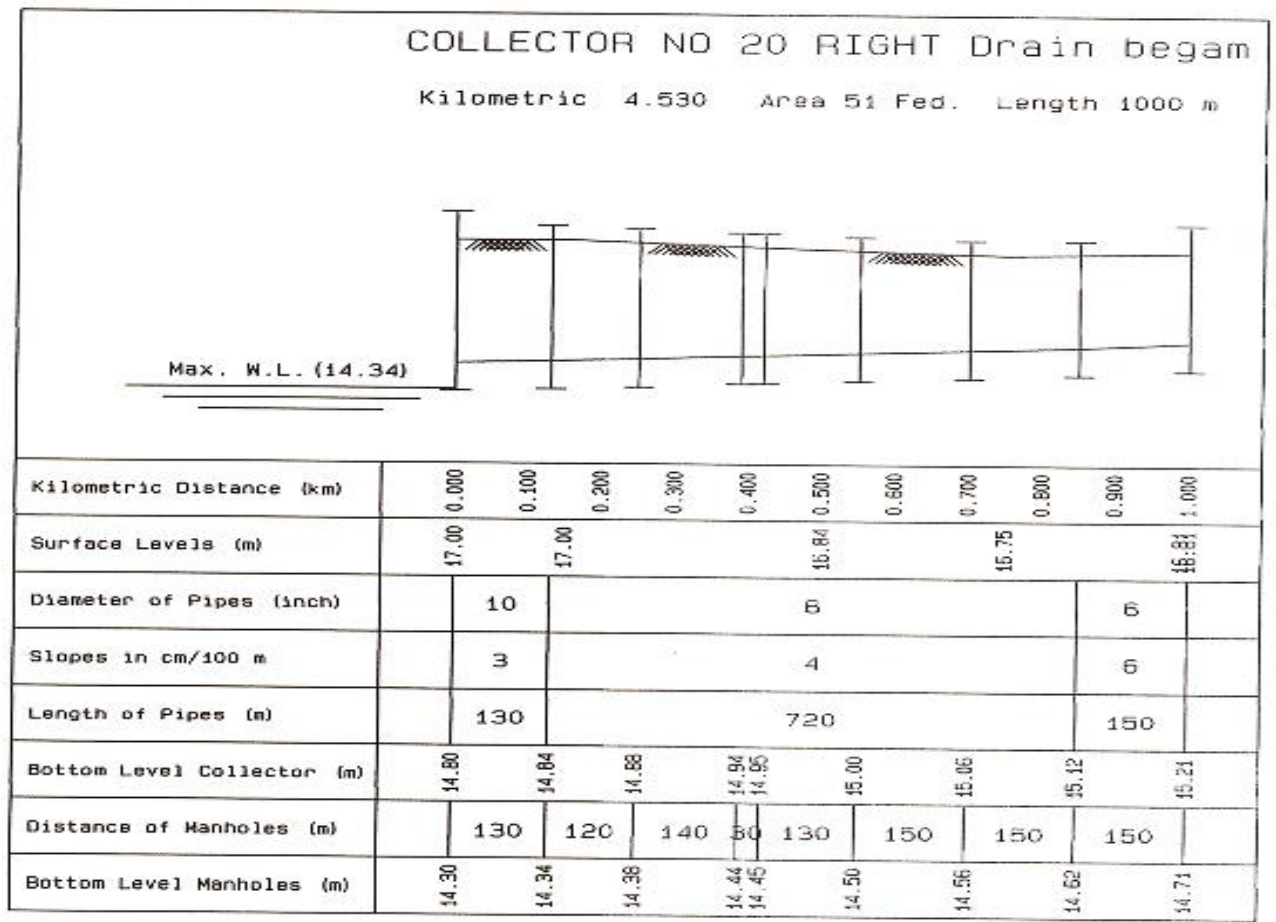

Fig. 1. Synoptic diagram of the (CDS)

\subsection{Soil physical properties}

Table 1, showed some physical characteristics of the soil. The clay percentage was approximately $65.2 \%$ and the soil could be classified as clayey soil.

Table 1. Some physical characteristics of the soil

\begin{tabular}{|l|c|c|c|c|c|}
\hline \multicolumn{3}{|c|}{ Particles size distribution (\%) } & \multirow{2}{*}{ Texture } & $\begin{array}{c}\text { Hydraulic } \\
\text { conductivity }\end{array}$ \\
\hline Clay & Silt & $\begin{array}{c}\text { Soft } \\
\text { sand }\end{array}$ & $\begin{array}{c}\text { Coarse } \\
\text { sand }\end{array}$ & Texnnnnnn \\
\hline 65.2 & 20.2 & 9.4 & 5.2 & $\begin{array}{c}\text { Clayey } \\
\text { soil }\end{array}$ & 0.095 m/day. \\
\hline
\end{tabular}

\subsection{Chemical composition of irrigation water}

Table 2, showed the chemical composition of irrigation water. The bicarbonate was the highest value followed by sulphates while chloride was the lowest value. On the other hand for cations, calcium was the highest value followed by magnesium then sodium and potassium was the lowest value.

Table 2. Some chemical composition of irrigation water

\begin{tabular}{|c|c|c|c|c|c|c|c|c|c|}
\hline $\begin{array}{c}\text { EC } \\
(\mathrm{dS} / \mathrm{m})\end{array}$ & Ph & \multicolumn{4}{|c|}{ Anions (meq/L) } & \multicolumn{3}{c|}{ Cations (meq/L) } \\
\hline \multirow{2}{*}{$\mathbf{0 . 4 8}$} & \multirow{2}{*}{$\mathbf{7}$} & $\mathrm{CO}_{3}^{-2}$ & $\mathrm{HCO}_{3}^{-}$ & $\mathrm{Cl}^{-}$ & $\mathbf{S O}_{4}^{-2}$ & $\mathrm{Ca}^{+2}$ & $\mathbf{M g}^{+2}$ & $\mathbf{N a}^{+}$ & $\mathrm{K}^{+}$ \\
\cline { 3 - 10 } & --- & 1.89 & 0.75 & 1.54 & 1.96 & 1.13 & 0.89 & 0.2 \\
\hline
\end{tabular}




\subsection{Modified drainage system (MDS)}

The design discharge was $1 \mathrm{~mm} /$ day. Drain depths were $0.90-1.00 \mathrm{~m}$ and the drain spacing were calculated according to the Hooghoudt's equation. The spacing between two laterals was $30 \mathrm{~m}$. The laterals were corrugated PVC pipes of $80 \mathrm{~mm}$ with an average length of $50 \mathrm{~m}$ and a slope design $0.1 \%$. The drain depth of lateral drains was
$0.9 \mathrm{~m}$ with minimum slope design of $0.1 \%$. The surface area was $(15+30+30+15)$ * $50=4500 \mathrm{~m}^{2}=$ 1.1 Fed. A buffer zone between the two designs was a must to avoid seepage and to obtain accurate results for each system separately. The surface area was about $(100 * 350)=35000 \mathrm{~m}^{2}=8.33$ Fed. Fig. 2, showed the two design systems (CDS), (MDS) and the buffer zone.

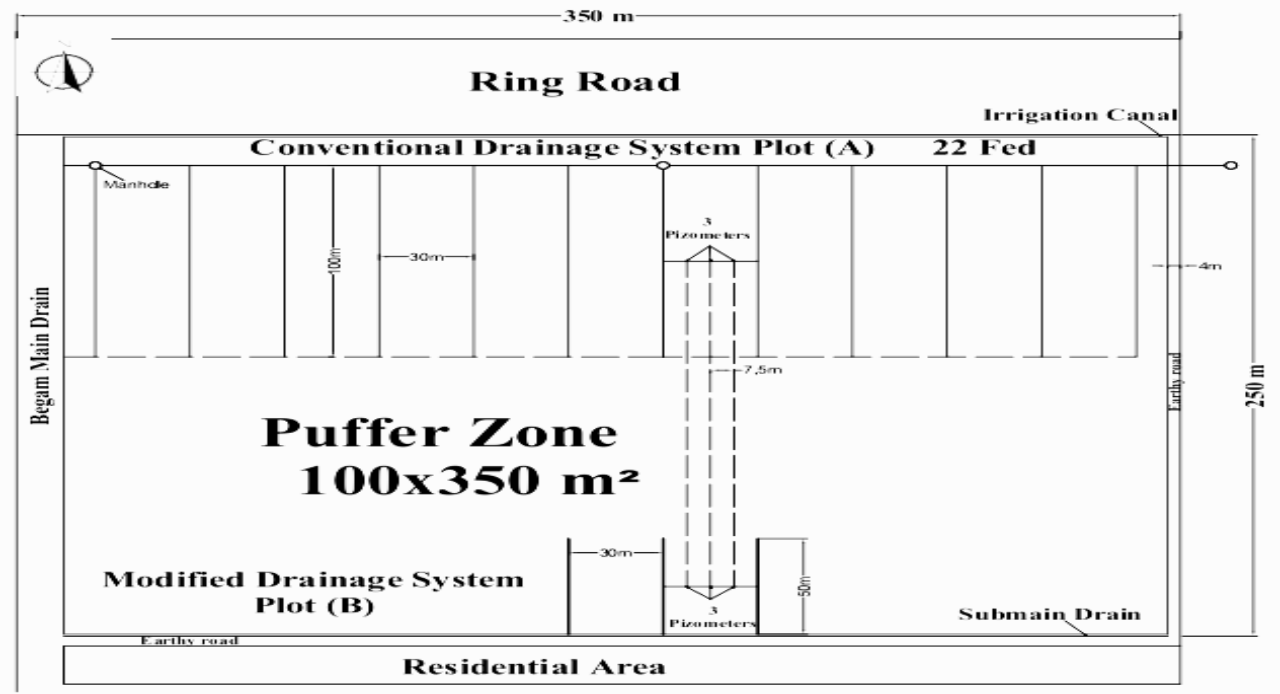

Fig. 2. Schematic of two design drainage systems

\section{METHODES}

\subsection{Lateral drains of (CDS)}

The total area of (CDS) was $350 * 100=35000$ $\mathrm{m}^{2}=8.33$ Fed. The depth of ground water table midway between two lateral drains was $0.9 \mathrm{~m}$. The design discharge was $1 \mathrm{~mm} /$ day. Drain depths were 1.5 and $1.7 \mathrm{~m}$. The design of the lateral spacing followed the steady state concept by using the Hooghoudt's equation as follows:

$$
S^{2}=\frac{8 k \cdot d_{e} \cdot h+4 K \cdot h^{2}}{q}
$$

Where:

(S) required drain spacing to control the water table $(\mathrm{m}),(\mathbf{K})$ the saturated hydraulic conductivity of the soil (m/day), (q) the specific discharge (m/day), $(\mathrm{H})$ the ground water table above drain level $(\mathrm{m})$, $\left(d_{e}\right)$ the equivalent depth of impermeable layer $(m)$ and $(\mathbf{h})$ the height of water at the midway between drains under stabilized condition (m). Fig. 3, showed the schematic of Houghoudt's drains spacing formula.

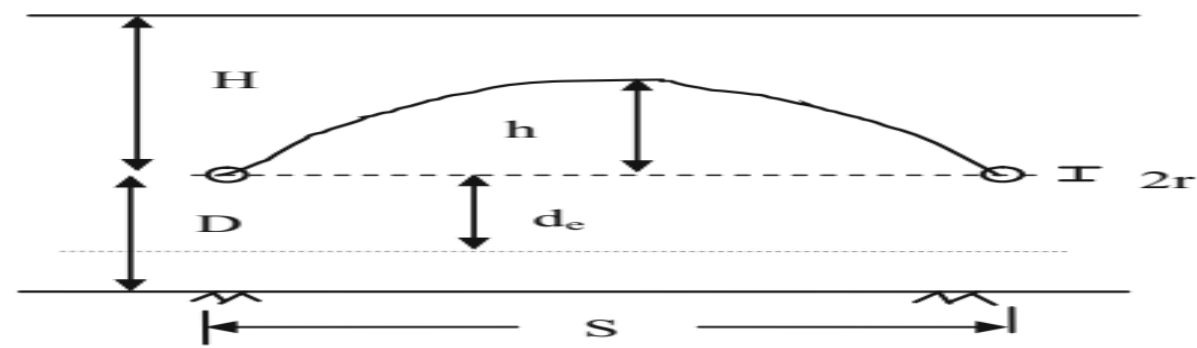

Fig. 3. Schematic of Hooghoudt's drains spacing formula

Arab Univ. J. Agric. Sci., Special Issue, 26(2B), 2018 


\subsection{Water table fluctuation}

A network of plastic piezometers $(5 \mathrm{~cm}$ diameter and $2 \mathrm{~m}$ length) was installed to measure water level between two laterals in the system by measuring the height of water that rise against gravity. The piezometer was used to measure the water vacillating inside the section of the soil between two lines of drainage system at distances (1/4, 1/2 and $3 / 4$ ) after and before each irrigation (Ritzema, 1994). Auger of $6 \mathrm{~cm}$ diameter was used to drill soil with depth $1.50 \mathrm{~m}$. The depth of water level in piezometers was measured after forty eight hours of the irrigation.

\subsection{Soil and water samples}

Twenty soil samples have been collected from each treatment (CDS and MDS). Five layers of $0.25 \mathrm{~m}$ from each location $(0-0.25,0.25-0.50,0.50$ $0.75,0.75-1.00,1.00-1.25 \mathrm{~m})$ for four irrigation were taken to measure soil salinity $\left(\mathrm{EC}_{\mathrm{e}}\right)$, cations $\left(\mathrm{K}^{+}, \mathrm{Na}^{+}, \mathrm{Mg}^{+2}, \mathrm{Ca}^{+2}\right)$ and anions $\left(\mathrm{SO}_{4}^{-2}, \mathrm{Cl}^{-}, \mathrm{HCO}_{3}\right.$ , $\left.\mathrm{CO}_{3}{ }^{-2}\right)$. At each application, samples of irrigation water were taken as well as samples from the drainage water for both systems (CDS and MDS). All water samples of irrigation and drainage were taken for cation and anion analysis.

\subsection{Drains spacing design}

\subsubsection{Conventional drainage system (CDS)}

Hooghoudt's equation was applied to calculate the spaces between the drains by trial and error method.

The trial assumed that: $S=30 \mathrm{~m}$ with $D=5 \mathrm{~m}$, concerning the values of (D), the investigations indicated that they were more than $10 \mathrm{~m}$ from the soil surface. The drainage criteria (q) used in the Nile Delta was $1 \mathrm{~mm} /$ day, depth of dewatering zone to reduce capillary salinization for heavy clay soil as recommended by (FAO, 1980) was $1.5 \mathrm{~m}$ and consequently design of hydraulic head $(h)$ was $0.5 \mathrm{~m}$. The calculation of equivalent depth (de) was according to Hooghoudt's tables, de $=2.38 \mathrm{~m}, \mathrm{k}=$ $0.095 \mathrm{~m} /$ day, and $\mathrm{q}=0.001 \mathrm{~m} /$ day. By applying the
Hooghoudt's equation and substituting the values of $k, h, q$ and de; using trial and error procedure;

$$
\text { So, } S^{2}=\frac{(8 * 0.095 * d e * 0.5)+\left(4 * 0.095 * 0.5^{2}\right)}{0.001}
$$

$\mathbf{S}^{2}=380$ de +95

The lateral drain spacing for (CDS) was $\mathbf{S}=$ $31.6 \mathrm{~m}$, it's closer to the imposition. Therefore, the design based on this assumption was the closest to the correct distance between the lateral pipe drains $S=30 \mathrm{~m}$ in the conventional drainage design.

\subsubsection{Modified drainage system (MDS)}

The trial assumed that: $S=30 \mathrm{~m}$ with $\mathrm{D}=5 \mathrm{~m}$, de $=2.38 \mathrm{~m}, \mathrm{k}=0.095 \mathrm{~m} /$ day, $\mathrm{h}=0.4 \mathrm{~m}$ and $\mathrm{q}=$ $0.001 \mathrm{~m} /$ day. By applying the Hooghoudt's equation and substituting the values of $\mathrm{k}, \mathrm{h}, \mathrm{q}$ and de; using trial and error procedure; the following was obtained

$$
S^{2}=\frac{(8 * 0.095 * d e * 0.4)+\left(4 * 0.095 * 0.4^{2}\right)}{0.001}
$$

$S^{2}=304 d e+60.8$

The lateral drain spacing for (CDS) was $\mathbf{S}=28$ $\mathrm{m}$, which is closer to the assumption. Therefore, the design based on this assumption was the closest to the correct distance between the lateral pipe drains so that the space between two laterals pipe was $30 \mathrm{~m}$ in the modified system (MDS) like in the conventional drainage system (CDS).

\section{RESULTS AND DISCUSSION}

\section{Irrigation water samples analysis}

Fig. 4, showed the EC $(\mathrm{dS} / \mathrm{m})$ of the irrigation water samples for the four irrigations. Data indicated that during irrigation periods salinity of irrigation water were almost similar and very low, they ranged between 0.47 and $0.50 \mathrm{dS} / \mathrm{m}$ with an average of $0.485 \mathrm{dS} / \mathrm{m}$.

Data also presented that $0.50 \mathrm{dS} / \mathrm{m}$ had the highest values followed by $0.49 \mathrm{dS} / \mathrm{m}$ and 0.47 $\mathrm{dS} / \mathrm{m}$ had the least value. 


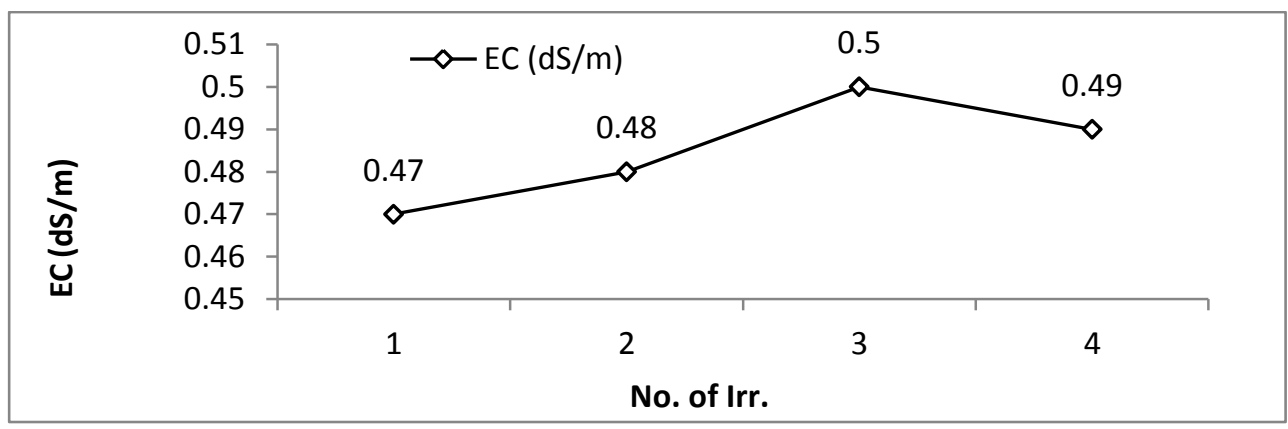

Fig. 4. $E C(d S / m)$ of irrigation water vs. No. of irrigation

\section{Soil samples analysis}

Fig. 5, indicated that salinity of the soil increased with increasing soil depth for both systems. This may due to high rate of leaching by irrigation. In the surface layer which is characterized by high porosity until reaching the deeper layers $(100-125 \mathrm{~cm})$ which the corresponding values were 2.5 and $2.7 \mathrm{dS} / \mathrm{m}$ for (MDS) and (CDS), respectively. The soil salinity of the (MDS) was

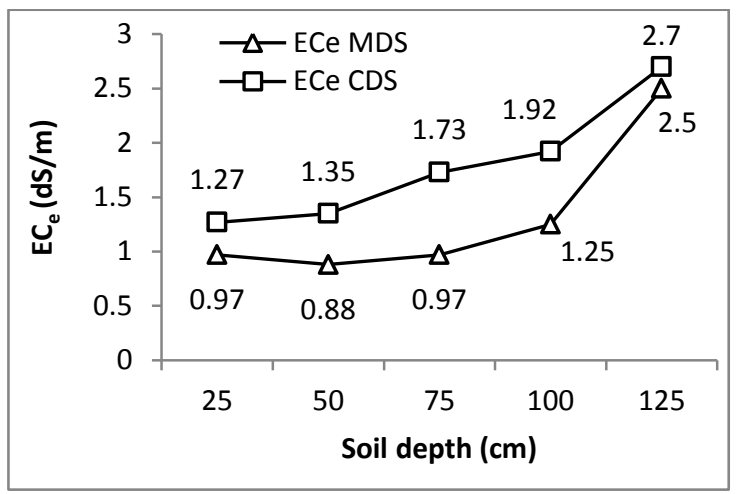

Fig. 5. Soil salinity $(\mathrm{dS} / \mathrm{m})$ in different layers between (CDS) and (MDS) for the $4^{\text {th }}$ irr.

Data in Fig. 7, showed that salinity of the soil decreased markedly with No. of irrigation. Experiments indicated that the salinity of the average soil profile decreased from second irrigation onward. The soil salinity of (MDS) was (47, 57 and $41 \%$ ) for $\left(2^{\text {nd }}, 3^{\text {rd }}\right.$ and $\left.4^{\text {th }}\right)$ irrigation, respectively. On the other hand, soil salinity of (CDS) was (40, 50 and $33 \%)$ for $\left(2^{\text {nd }}, 3^{\text {rd }}\right.$ and $\left.4^{\text {th }}\right)$ irrigation, respectively. On the first irrigation, the first layer of (MDS) soil salinity showed higher value than the corresponding value of the (CDS) by $1.5 \%$. The presence of high evaporation from soil surface during first irri- lower than (CDS) for all depths which attributed to the good performance and hydraulic functioning of the (MDS) than the one (CDS). Fig. 6, presented the average chloride distribution in the soil profile during the irrigation season, obtained from soil samples. The chloride ion didn't precipitate due to its high solubility or reacted with the adsorption complex. So it was an excellent tracer for water and salt movement.

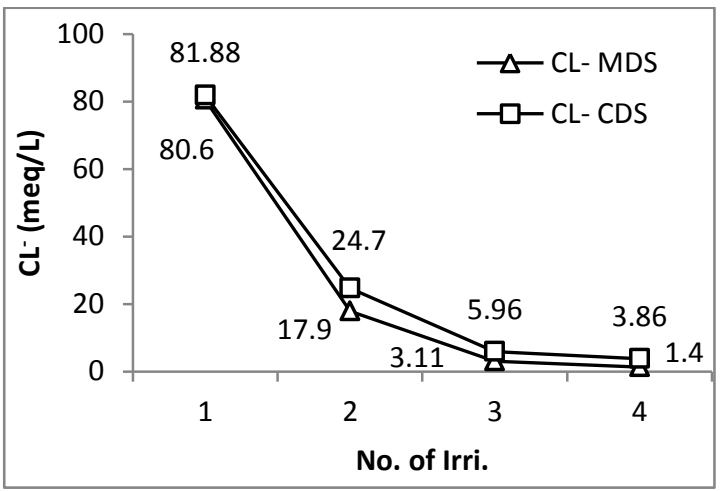

Fig. 6. $\mathrm{Cl}^{-}(\mathrm{meq} / \mathrm{L})$ of average profile of the soil for (CDS) and (MDS) vs. No. of irr.

gation after fallow period was the reason for the increased salinity for the first layer. By comparing between two design systems, the soil salinity of (MDS) was better than that of (CDS). The decreasing ratios between the two systems after the $\left(2^{\text {nd }}\right.$, $3^{\text {rd }}$ and $\left.4^{\text {th }}\right)$ irrigation, were $(15,12$ and $19.5 \%)$, respectively.

Fig. 8, showed the relationship between $\mathrm{pH}$ and number of irrigation through the season of the soil profile. Through the season, the $\mathrm{pH}$ decreased with the increase in the number of irrigations. The soil was leached every irrigation. There was a dif- 
ference between the two design systems. In the new drainage design system, the leaching of the soil happened in few layers. While in the conventional drainage design system, the leaching of the

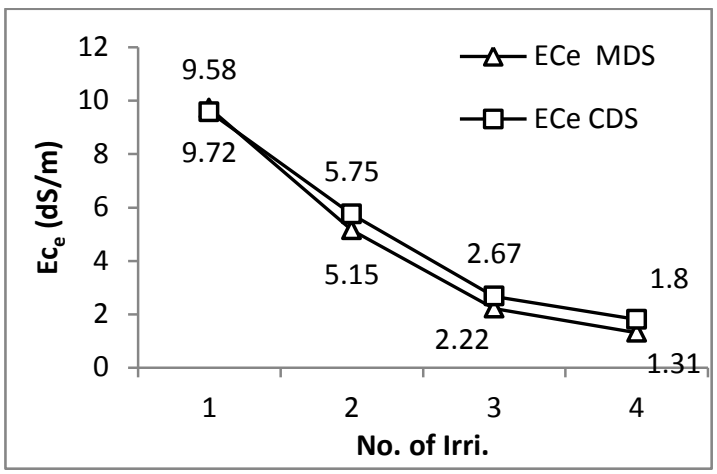

Fig. 7. Soil salinity $(\mathrm{dS} / \mathrm{m})$ of average profile of the soil for (CDS) and (MDS) vs. No. of irr.

\section{Height of piezometer base and drainage rates}

Generally, the (MDS) was less in depth than the (CDS). The water table didn't exceed barrier of drain depth in both systems. Before the $1^{\text {st }}$ irrigation, the water table was away because the soil was fallow for a long period of time. After the $1^{\text {st }}$ irrigation, the piezometer readings were high and the soil was saturated with water as shown in Fig. 9. The measurements of water table showed that the water table levels reached the soil surface upon irrigation and dropped until they reached a low level before the next irrigation. Such general trend soil happens in more layers. So, the drainage water that was collected in the new drainage design system was lower in salinity than the conventional drainage design system.

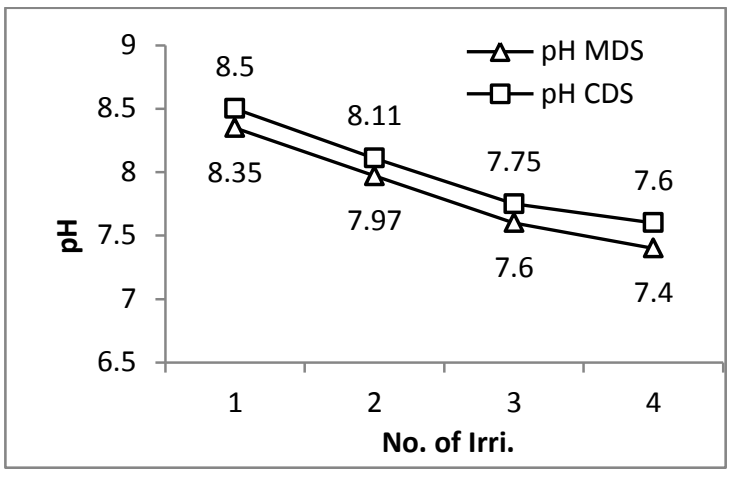

Fig. 8. $\mathrm{pH}$ of average profile of the soil in (CDS) and (MDS) vs. No. of irr.

was observed in both systems. Piezometers were installed to measure the water table depth in all treatments and convert the water table depths into hydraulic head values. (Hydraulic head = drain depth - water table depth). The average values of water table depth after first irrigation were 14.5 and $11 \mathrm{~cm}$ for (MDS) with 1/4 and 1/2 distances between the drain lines, respectively. The corresponding values for (CDS) were 29.5 and $24 \mathrm{~cm}$ the drop of water table was faster in 1/4 distance than midway between the drain lines. This may be attributed to the higher effectiveness of drainage system near the drain line than far from the drain line.

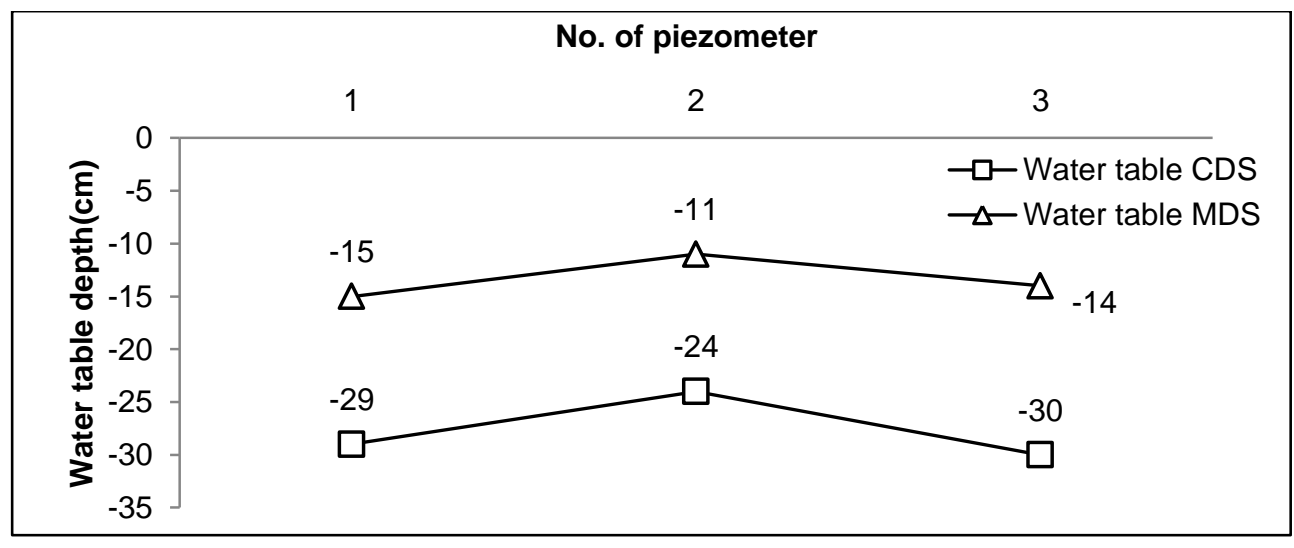

Fig. 9. Water table depth (cm) after $1^{\text {st }}$ irr. for both (CDS) and (MDS) 
Figs. 10. and 12, showed that the water table level decreased in both design systems before the $2^{\text {nd }}$ and $3^{\text {rd }}$ irrigation. In the (CDS), the water table was so deep to the plants to benefit from the water table directly.

Figs. 11. and 13, showed that the water table level rose after the $2^{\text {nd }}$ and $3^{\text {rd }}$ irrigation. The water table level in each side was low near to the drainage pipes, while it was high in the middle of drainage pipes. Water table level decreased with time to reach the drainage pipe level, but the (MDS) was higher than the (CDS). The (MDS) raised the water table near to the root zone, so the plants can benefit from the water table directly.

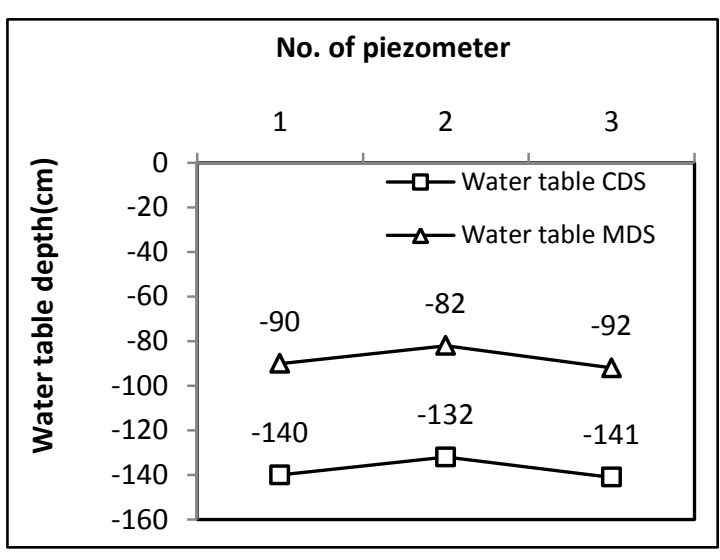

Fig. 10. Water table depth $(\mathrm{cm})$ before the $2^{\text {nd }}$ irr. for both (CDS) and (MDS).

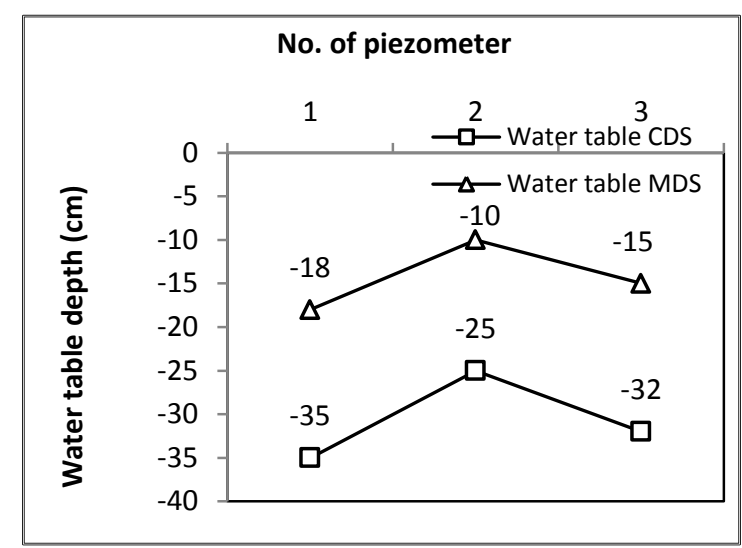

Fig. 11. Water table depth $(\mathrm{cm})$ after the $2^{\text {nd }}$ irr. for both (CDS) and (MDS)

1. 1/4 distance from drain line. 2. 1/2 distance from drain line. 3. 3/4 distance from drain line.

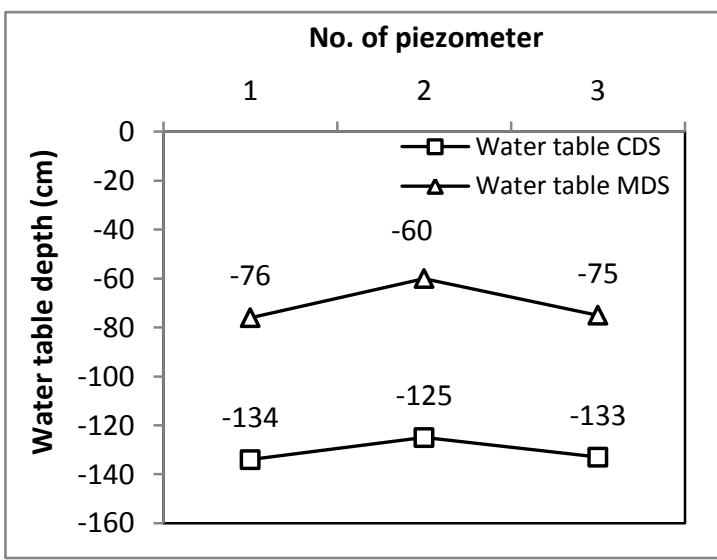

Fig. 12. Water table depth $(\mathrm{cm})$ before the $3^{\text {rd }}$ irr. for both (CDS) and (MDS).

\subsection{Hydraulic head for both systems}

The obtained data of water table levels for the investigated treatments were reflected on hydraulic head Fig. 14 and also Fig. 15, where an almost

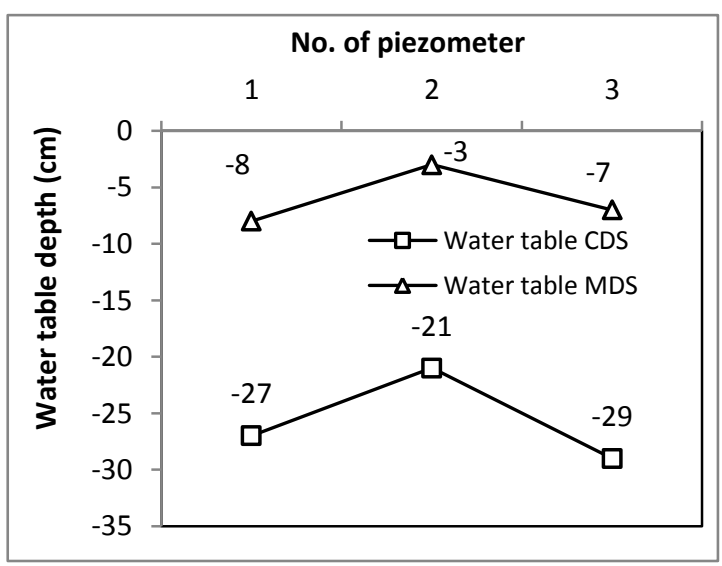

Fig. 13. Water table depth $(\mathrm{cm})$ after the $3^{\text {rd }}$ irr. for both (CDS) and (MDS).

opposite trend to that encountered with water table depth was recorded. The results indicated a relatively higher value of water table and lower values of hydraulic head for all treatments. 


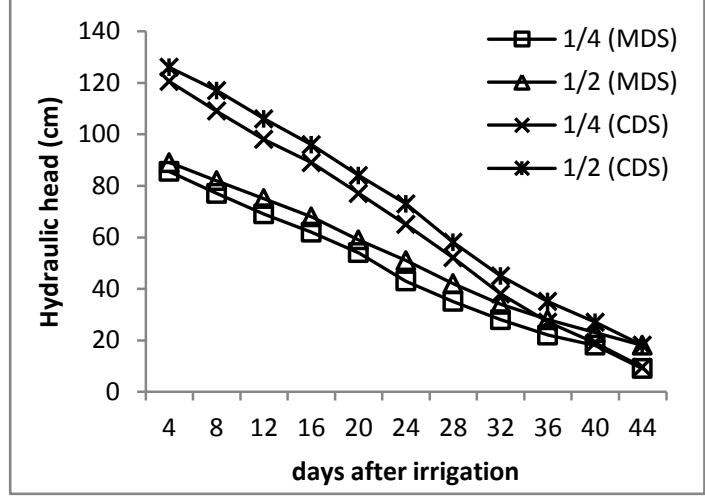

Fig. 14. Hydraulic head for (MDS) and (CDS) between the $1^{\text {st }}$ and $2^{\text {nd }}$ irr.

\subsection{Water table depth at the midway distance of drains}

Measurements of water table drawdown Figs. 16 and 17, between two lateral drains were recorded to compare between both systems (MDS) and (CDS). Results recorded the highest water table after irrigation at (1/4 distance from the drain line) which was $(14.5,16.5$ and $7.5 \mathrm{~cm})$ for $\left(1^{\text {st }}, 2^{\text {nd }}\right.$,

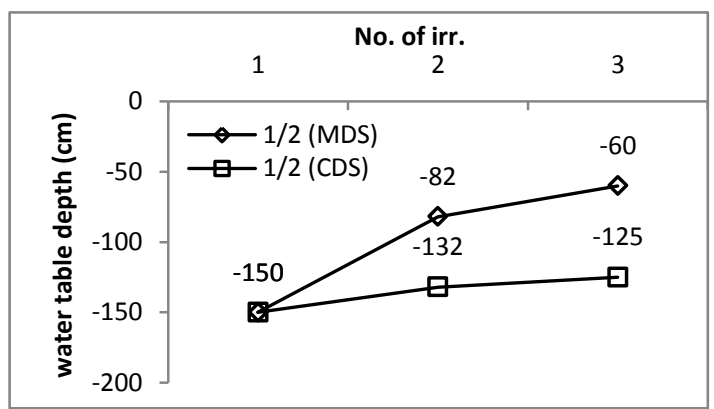

Fig. 16. Water table depth at the midway distance of drains before irr. vs. No. of irr.

\section{Drainage water samples analysis and plant productivity}

Fig. 18, indicated that the salinity of drainage water increased with depth and the (MDS) produced drainage water with higher quality and lower salt concentration than the (CDS). The EC values of drainage water of (MDS) decreased from the first irrigation onwards. The EC values of drainage water salinity of (MDS) were (1.32, 1.18, 0.94 and $0.64)$ for $\left(1^{\text {st }}, 2^{\text {nd }}, 3^{\text {rd }}\right.$ and $\left.4^{\text {th }}\right)$ irrigation, respective-

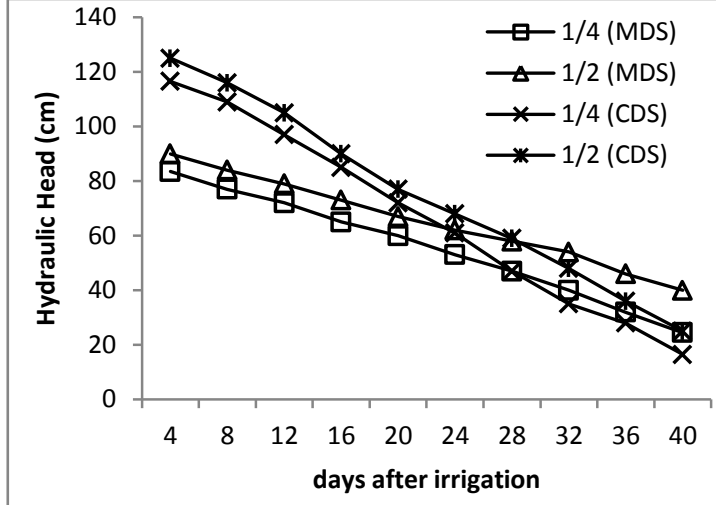

Fig. 15. Hydraulic head for (MDS) and (CDS) between the $2^{\text {nd }}$ and $3^{\text {rd }}$ irr.

and $3^{\text {rd }}$ ) irrigation for (MDS), respectively and $(29.5,33.5$ and $28 \mathrm{~cm})$ for $\left(1^{\text {st }}, 2^{\text {nd }}\right.$, and $\left.3^{\text {rd }}\right)$ irrigation for (CDS), respectively. At (1/2 distance from the drain line), the depths were $(11,10$ and $3 \mathrm{~cm})$ for $\left(1^{\text {st }}, 2^{\text {nd }}\right.$, and $\left.3^{\text {rd }}\right)$ irrigation for (MDS), respectively and $(24,25$ and $21 \mathrm{~cm})$ for $\left(1^{\text {st }}, 2^{\text {nd }}\right.$, and $\left.3^{\text {rd }}\right)$ irrigation for (CDS), respectively. The results showed that the water table depth was deeper for (CDS) than for (MDS).

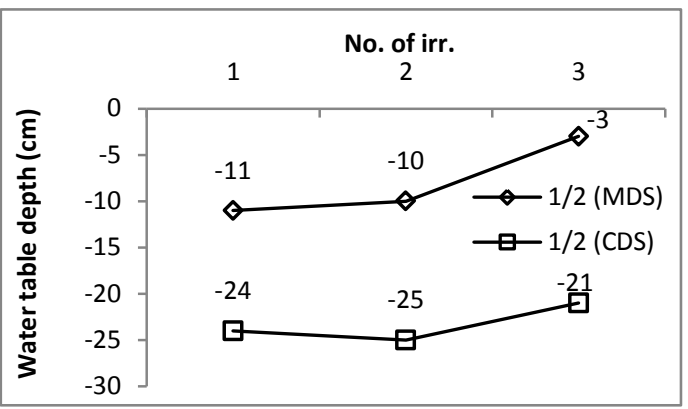

Fig. 17. Water table depth at the midway distance of drains after irr. vs. No. of irr.

ly. On the other hand, the EC values of (CDS) were $(1.42,1.33,1.25$ and 0.9$)$ for $\left(1^{\text {st }}, 2^{\text {nd }}, 3^{\text {rd }}\right.$ and $4^{\text {th }}$ ) irrigation, respectively. The EC percentages of drainage water salinity of (MDS) were $(10.6,18.2$ and 22.7) for $\left(2^{\text {nd }}, 3^{\text {rd }}\right.$ and $\left.4^{\text {th }}\right)$ irrigation, respectively. On the other hand, the EC percentages of (CDS) were $(6.3,5.6$ and 24.6$)$ for $\left(2^{\text {nd }}, 3^{\text {rd }}\right.$ and $\left.4^{\text {th }}\right)$ irrigation, respectively.

As the water table dropped, the water flow paths to the drains became deeper. The drain flow at deeper water table depths had a greater domi- 
nance of deeper water flow paths, which moved water through the deeper soil profile, that is more saline. On the other hand, water table salinity during the recession of water table increased with depth to reach the maximum value at the deepest layer. Therefore, the salinity of the drainage water sample of the (CDS) was more obvious than the (MDS) due to the difference in drain depth.

Data also indicated that $\mathrm{pH}$ and SAR decreased with increasing No. of irrigation and the values of (CDS) were higher than the (MDS) Figs. 19 and 20.

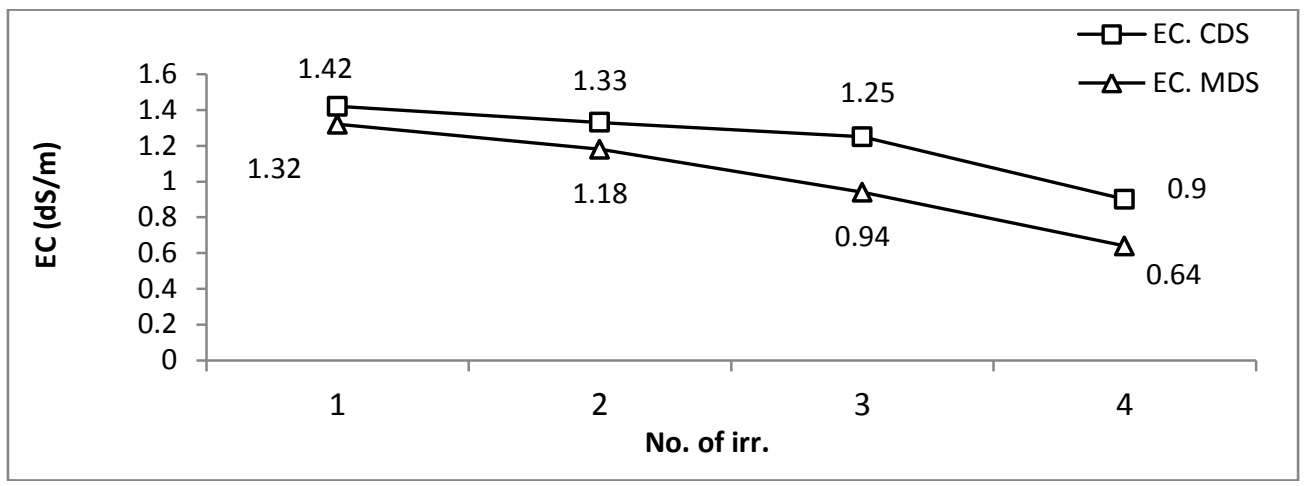

Fig. 18. Drainage water salinity $(\mathrm{dS} / \mathrm{m})$ for both (CDS) and (MDS)

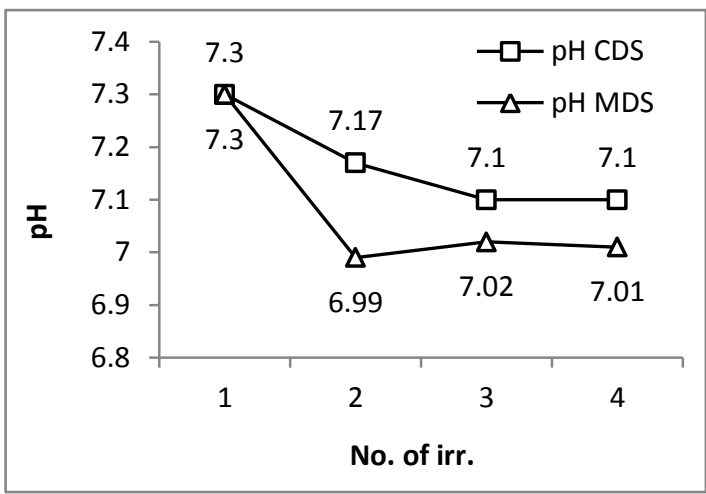

Fig. 19. Drainage water $\mathrm{pH}$ for both (CDS) and (MDS).

Table 3, showed that there was no significant difference between the two design systems (CDS) and (MDS). The drain depth didn't have any effect on the productivity. The productivity in two systems was 3.5 tons/fed.

Table 3. Showed the plant productivity of (CDS) and (MDS)

\begin{tabular}{|c|c|c|}
\hline System & CDS & MDS \\
\hline Productivity (ton/fed) & 3.5 & 3.5 \\
\hline
\end{tabular}

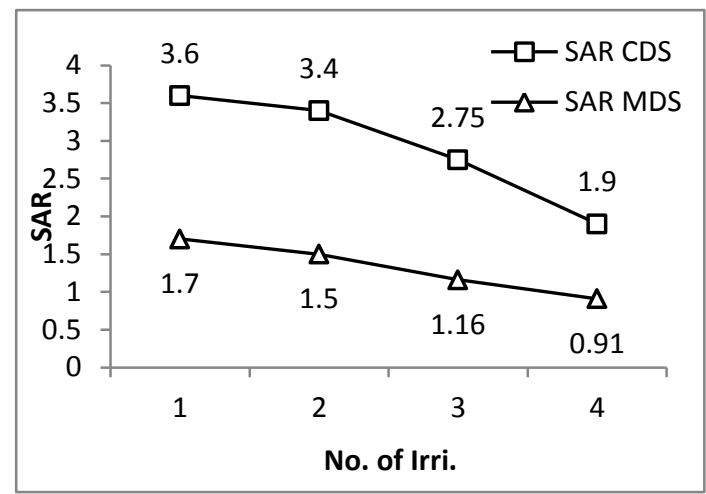

Fig. 20. Drainage water SAR for both (CDS) and (MDS).

\section{CONCLUSIONS}

Results showed that it is advisable to install the drainage network at a depth of $1.0 \mathrm{~m}$, instead of the deep drainage at $1.5 \mathrm{~m}$ as used at present time in Egypt. It can be concluded that, the shallower drain depth of tile drainage system (MDS) had an effect on reducing soil salinity at acceptable levels. It also, decreased the cost of reused drainage water that comes from the deeper drains. Moreover, it saved the additional cost to install the deeper drains. There is no significant difference in productivity between the two systems. The obtained data in this study revealed that shallower drain depth 
was the optimum to decrease the salt load in the drainage network to get water with a good quality which can be used directly in agriculture or after blending with fresh water. Although the irrigation scheduling was not a part of this research, it is likely that with a shallower ground water depth due to restricted drain flow; the irrigation schedule could be adjusted, using longer periods between irrigation applications. An integrated approach to irrigation and drainage management is recommended, compared to only drainage management.

\section{REFERENCES}

Abdel-Dayem, M.S. 1998. "Development of land drainage in Egypt", Drainage Research Institute, Giza, Egypt, pp. 49-54.

Anupam, P. 2013. "Agricultural Drainage and Water Quality, Discovery Pub. House PVT". LTD. New Delhi, India, pp. 3-80.

Ayers, J.E., Grismer, M.E. and Guitjens, J.C. 1997. "Water quality as design criterion in drainage water management." J. Irrigation and drain. Engrg., ASCE, 123(3), 154-158.

Christen, E.W. and Skehan, D. 2001. "Design and Management of Subsurface Horizontal Drainage to Reduce Salts Loads". ASCE J. Irrigation and Drainage 127(3), 148-155.

Dugas, W.A., Meyer, W.S., Barrs, H.D. and Fleetwood, R.J. 1990. "Effects of soil type on soybean crop water use in weighing lysimeters. Root growth, soil water extraction and water table contributions". Irrigation Sci., 11, 77-81.
FAO, 1980. "Drainage design factors". Irrigation and Drainage paper No. 38, Rome, 52 p.

FAO, 2002. "Agricultural drainage water management in arid and semi-arid areas." Rome, Italy. $73 \mathrm{p}$.

FAO, 2007. "Guidelines and computer programs for planning and design of land drainage systems". J. Martinez Beltran, 1999. "Water Development and Management Unit". Rome, Italy, pp. 87-88.

FAO, 2014. Aqua stat database. Retrieved Sept. 29, 2014, http:// www. FAO. Org/nr/water/aqua state/main/index.stm.

Grismer, M.E. 1993. "subsurface drainage system design and drain water quality." J. Irrigation and drain. Engrg., ASCE, 119(3), 537-543.

Norman, R.F. and Randy, D.B. 1976. "Shallow subsurface drainage field performance", Transactions of the ASAE 19(6), 1082-1088.

Ritzema, H.P. 1994. "Drainage principles and applications", (ILRI) pub.16, The Nether lands, Chap, 17, pp. 24-38.

Ritzema, H.P., Satyanarayana, T.V., Raman, S. and Boonstra, J. 2008. "Subsurface drainage to combat waterlogging and salinity in irrigated lands in India: Lessons learned in farmers' fields" Sci. Direct, 95(3), 179 - 189.

Ritzema, H.P. 2009. "Drainage for Gain, Subsurface Drainage Practices in Irrigated Agriculture in Semi-Arid and Arid Regions", Wageningen Univ., and UNESCO-IHE Institute, the Netherlands, pp. 15-98. 